\title{
Hierarchy of Values and Lifestyle of Managers
}

\author{
Barbara Mróz* \\ Institute of Psychology, University of Opole, Poland
}

Received: 眥: October 08, 2018; Published: 眥: October 16, 2018

*Corresponding author: Barbara Mróz, Institute of Psychology, University of Opole Pl. Staszica 1, 45-052 Opole, Poland

\begin{abstract}
Objective: The objective of this paper is to present issues resulting from the theory of economics and management psychology, including their implications for company management practice and for their impact on workers' well-being and values. Research in psychology of management demonstrated that effective employee management requires, first of all, personal, social skills and values on the part of the manager.

Method: In order to verify the questions and hypotheses proposed, a well-known research tool has been applied the Rokeach's Value Survey and Study of Values by Allport, Vernon, Lindsey. A version of Rokeach's RVS was applied to measure the hierarchy of values among managers in a medium-sized automotive company which is planning reorganization.

Results: The results obtained in this study significantly differentiated the women and men with respect to their ultimate values. The following values appeared to be the most statistically differentiating: "outstanding successes" (0.001), "social recognition", "enjoyment of life" (0.001) and "comfortable life" (0.05). Within the selected lifestyle, the participants ranked values in the following order: economic, social, political, aesthetic, religious, and theoretical.

Conclusion: The article clearly shows the role of the hierarchy of values for managers' functioning during changes. This is also significant in any changing economic reality (emerging economies, emerging markets). Manager values are important in many changing or emerging economies - not only in management - for developing competitiveness and economic growth. This know-how opens up greater possibilities for applying the theory in practice.
\end{abstract}

Keywords: Management Psychology; Hierarchy and Structure of Values; Lifestyle; Managers

\section{Introduction}

Although a manager has influence on the shape of the professional space in the company, he/she needs to take into account both the external (market, legal, and social) and internal (personality, intellectual, age, and experience) limitations on the effects of its operations presenting the manager with many complex problems. His/her operations result in how a company functions, its resources, prospects, and in its possibility for further development. While demonstrating the manager's complex operations, attention to managerial theory should also be paid. It is assumed that company management, with its efficient implementation of four elements - planning, organizing, leading and controlling - is not only the art of mastering and implementing technical skills; it is also the art of applying social and personal skills Kozminski [1]. Management skills can be discussed in respect to the area of the manager's operations and responsibility for management.

Based on Katz's theory Katz [2], the relationships between effective personnel management and the workers' place and role in a company can be analysed. According to Katz, there are three elementary skills necessary for all managers - technical skills, social skills, and conceptual skills. The ratios of particular type of these skills may vary at different managerial levels Stoner and Wanker [3]; Katz [2]. Technical skills are the ability to use tools, methods or process technology. An accountant, secretary, or specialist must possess technical skills in their fields. A manager also needs to have such skills, however, only to the extent which enables him/ her to communicate effectively in that specific field. Social skills are the ability to co-operate with other people and to communicate effectively with both groups of employees and individuals from these groups. A manager's social skills are necessary within such a scope so that they enable him/her to cooperate and facilitate leading a team.

Conceptual skills are the mental acuity to co-ordinate and integrate all interests and operations within a company, requiring the capacity to perceive an organization as a whole, as well as to understand how an activity of any part of the organization will influence it as a whole. The manager needs to possess conceptual skills in order to anticipate influences and relationships among different departments of the company and to make decisions which serve the whole organization best. Such a way of perceiving management skills is accepted, as a rule, by both psychologists 
and economists who specialize in management Kozminski [1]. However, many of them also emphasize the importance of personality characteristics in management. It has been suggested that strongly connecting social skills and emotional intelligence with a management style based on targets is not only a trend in theoretical research but is also necessary for effective management Kożusznik [4]; Mróz [5]. While presenting Donald E. Super's theory Super [6,7], E Hornowska and JW Paluchowski Hornowska and Paluchowski [8] underlines its eclecticism and indicates great practical possibilities associated with its application.

According to Super, from an individual point of view, a professional career is perceived as a description of successive lifetime decisions, and the theory is based on such concepts as value, involvement, and self-assessment. One's professional image is shaped by the amount of experience (work observations and identifying with other employees). As the work experience becomes wider and wider, the individual's professional image also becomes richer Hornowska, Paluchowski [8]. A manager's talent for making use of all his/her personality traits optimizes not only his/her professional sphere but also the personal one. Similar assumptions and objectives lie behind Goleman's concept of personality. Goleman at first concentrated on general development, or education; yet later he reached conclusions which considerably exceeded this area of a person's activities Goleman [9]. In his research, Goleman demonstrated that effective employee management requires, first of all, personal and social skills on the part of the manager.

He focused on emotional intelligence as a factor responsible for managerial efficiency at different levels. Goleman's works determined a new direction for research into an individual's more effective behavior aimed at changing social and economic realities Goleman [9]; Mróz [10,11]. Both the labour market and its requirements have significantly changed over the last 18 years. Besides emotional intelligence, Goleman also distinguished two characteristics which play an important role in being a successful manager, involving the ability to create teams and the extent to which one can adapt to changes. It is interesting to follow the changes in research topics with which theoreticians of psychology and economics have dealt over the last ten years. Similar conclusions can also be reached among managers Hawkins [11]; Roztocki and Weistroffer [12]; Sey et al. [13].

\section{Management Concept: Lean Manufacturing and Toyota's Concern Principles}

Among many management theories, two especially constitute examples of interesting solutions in combining organizational structures with personal structures in a company. This paper pairs the Lean Manufacturing concept with Toyota's concern principles, which are an important method used by management to benefit from employee know-how in implementing organizational changes in the staff environment. The concept of Lean Manufacturing aims at eliminating wastage in manufacturing, which is erroneously perceived by practitioners only as a technical tool that streamlines the flow of materials through all their stages Womack and Jonem [14]. This misunderstanding consists in believing that making changes is the responsibility of the management staff only Hornowska and Paluchowski [15]; Mróz [10]. In fact, the aim of Lean Manufacturing is to constantly reduce wasted time, material, and employees' power - all energy understood as any activity, process or investment which does not add any value to the product from the Client-Patient point of view. Examples of waste in a nurses' working environment may include:

a) Waiting.

b) moving - making unnecessary movements.

c) unplanned technical activities.

d) unplanned work stoppage of sections.

e) inventory exceeding minimum levels.

f) excessive transport of products necessary to operate a given ward.

g) inadequate working methods.

h) shortages Czerska [16]; Mróz [17].

Each organization or enterprise aims at reducing production costs, and therefore the Lean Manufacturing method is more and more widely applied by both Polish companies and public benefit organizations which have succeeded in eliminating activities that do not add value to the basic product and related tasks Czerska [16]. In the early stages of implementing Lean Manufacturing it may seem that transforming an organization (a hospital, a company, a school) requires radical changes. However, contrary to a popular belief and fear, implementing Lean Manufacturing is not tantamount to reducing employment but a means continuing to increase work effectiveness by decreasing low-quality services or goods Czerska [16]; Mróz [18]. On the other hand, the Toyota concern management principles are based, to a great extent, on projecting and sustaining high workstation organizational standards Liker [19]. The philosophy of sustained improvement dominates, as well as the involvement of employees at all organizational levels in the improvement programs. Additionally, production management is based on a short processing time, production adjusted to the number of orders, and continuous quality control at critical manufacturing stages. The above-mentioned principles are associated with farreaching visions in order to transform the aims into creative and bold realities Mróz [18]; Hawkins [11].

\section{Management Concept: The Role of the Hierarchy of Values}

Humans can choose and live according to various lifestyles. Most frequently they represent an externalized world within a system of values. If the hierarchy of values is coherent, it may in future, in difficult or extreme situations, constitute a source of support for an individual Kozminski [1]. The values may also become a source of emotions, resulting from an evaluative attitude towards the social background Mróz [20,15]. In a study analyzing the hierarchy of values among young managers, the author found that "responsibility" - placed by Rokeach in the group of instrumental 
values - differentiated the subjects Mróz [5]. The managers' group most often used encouragement - as seen in Rokeach's first three instrumental values: "ambition", "independence" and "courage" Rokeach [21]. The managers' group most often suggested that the workers should enlarge their range of responsibility. Young managers who used salary as a motivator relied more on themselves.

They were convinced about their own strengths for professional success, and were characterized by less thinking, fewer insights, more fears, and were also less ready to apply full procedures, though based on ethical principles to a large degree. In their turn, young managers applied the motive of joint responsibility for work to be done. They realized management aims by choosing social values to a greater extent. Spranger's theory, on the basis of which a research method applied in this study was developed, categorizes values into the following types: economic, esthetic, political, religious, social and theoretical. The quantitative and qualitative selection of a value constitutes a particular lifestyle Mróz [10]; Allport [22].

\section{Material and Methods}

This study investigated the hierarchy of values among managers in a Polish private medium-sized automotive company. The company plans to reorganize and assumes that, as a primary step in the acceptance of changes, there will be a willingness to cooperate in their implementation. Previous research on the hierarchy of values has shown that its stability depends on the intensity or level of choice among the particular categories. This is the way in which values are presented in Rokeach's theory, which also worked out a research method. According to Rokeach's hypothesis the hierarchy of values is topped by those values representing dominant needs, while the lower ranks are filled with values corresponding either to needs already satisfied or unrevealed due to a lack of appropriate circumstances Rokeach [21]. The ultimate value is tantamount to such statements as "I believe that such and such ultimate goal, for example the world at peace, equality of all people, or salvation personal or social - is worth fighting for" Rokeach [23].

The theory assumes that a specific mode of conduct is individually and socially more attractive than other ways of behavior and aims in life. In addition, the values in this theory also refer to cognitive, motivational, emotional, and behavioral spheres Rokeach [21,24]. For Rokeach, values are dual in nature. Some of them can be viewed as ultimate human aspirations and some as means and instruments for realizing ultimate values. His questionnaire entitled "Value Survey" has been known and described in psychology since 1973 Rokeach [23]. It contains 18 values. The lower the rank attributed to a value, the greater the importance of a value. The correlation coefficients between the Polish and English versions of the questionnaire were .99 and .98 respectively. The Pearson $r$ coefficients for individual values averaged .79 Brzozowski [25,26]. Rokeach's method was chosen for this study because it had already been adapted to Polish standards and used for exploring managerial values since 1994. The test also has a long tradition of being applied in Poland. Rokeach's "Value Survey" as well as the Evaluative Attitude Notebook (Study of Values) by G. Allport, P. Vernon and G. Lindsey in the authorized translation by M. Choynowski have been used in the study Allport [22]; Brzozowski [27].

\section{The following hypotheses were proposed in this study:}

i) It seems that in such a specific professional group as managers in a automotive company, research participants will rather focus on individual values, with health ranked highest.

ii) Bearing in mind that they are overloaded with formalized work, they will devalue the values associated with such overload in their working environment.

The study was carried out in a group of 90 managers (60 women and 30 men, in the field of automotive). aged from 29.1 to 43.5 , on average 35.2 years old. All of whom consented to their participation in the study.

\section{Results}

The findings show that the most stable values were those rated most highly and those rated least highly, which is typical for all ranking techniques. The structure of ultimate values in the sample is shown in Table 1, and the percentage distribution of the most and least preferred values is presented in Table 2.

\section{Table 1 Ranking of Ultimate Values in The Group of Managers of an Automotive Company ( $\mathrm{N}=90)$}

The ultimate values rated most highly by the managers were as follows: health (68\% of choices at the first three ranks), self-esteem (65\%), and supporting one's family (63\%). The least approved values were the following: national health (53\%) (at the last three ranks), adventurous life (55\%), and beauty of the world (61\%).

Table 1: Ranking of ultimate values in the group of managers of a automotive company $(\mathrm{N}=90)$.

\begin{tabular}{|c|c|c|c|}
\hline Ultimate values & Mean & Median & SD \\
\hline Safety & 16.40 & 10.0 & 3.7 \\
\hline Mature love & 7.90 & 9.5 & 4.0 \\
\hline Wisdom & 8.05 & 4.5 & 3.7 \\
\hline Beauty of the world & 16.80 & 10.5 & 4.7 \\
\hline Peace in the world & 12.20 & 11.0 & 5.6 \\
\hline True friendship & 8.90 & 8.0 & 4.1 \\
\hline Enjoyment of life & 12.70 & 9.5 & 1.7 \\
\hline Equality of people & 15.30 & 11.0 & 3.3 \\
\hline Outstanding successes & 10.30 & 8.5 & 5.1 \\
\hline Self-respect & 2.90 & 9.0 & 3.7 \\
\hline Social recognition & 10.90 & 10.0 & 5.5 \\
\hline Inner peace and harmony & 11.70 & 5.5 & 3.0 \\
\hline Personal freedom & 4.90 & 7.0 & 3.1 \\
\hline Comfortable life & 15.40 & 8.0 & 4.4 \\
\hline Providing financial & 3.80 & 8.5 & 3.1 \\
\hline support for the family & 13.70 & 13.5 & 3.2 \\
\hline Salvation & 2.60 & 5.0 & 2.5 \\
\hline Health & 16.40 & 11.0 & 2.1 \\
\hline Exciting life & & & \\
\hline
\end{tabular}




\section{Table 2 Percentage Share of Ultimate Values Which Were Most and Least Preferred by Managers (N=90)}

The high positions of "self-esteem" and "supporting one's family" are interesting as well as the choices of values which are rejected. Rokeach stresses that the test results may be interpreted as needs or things missing, not as values fulfilled, and therefore ranked so highly Rokeach [23,24]. The participants present themselves as individuals full of anxiety about themselves - their health and personal matters - as well as about maintaining their homes and supporting their families. It unlikely that they will eagerly implement the changes proposed by the employer, as reserve and resistance tend to dominate among them. This means that the managers have a greater sense of workplace instability; they feel insecure and have low self-confidence, especially with respect to their own knowledge. Similar conclusions are drawn by Oleś and Kozminski in their research Oleś [28,29]; Kozminski [1]. The managers ranked the following values according to the lifestyles they had selected: economic, social, political, esthetic, religious, and theoretical values Allport [22]; Mróz [5].

Table 2: Percentage share of ultimate values which were most and least preferred by managers $(\mathrm{N}=90)$.

\begin{tabular}{|c|c|c|c|c|}
\hline \multirow{2}{*}{ Ultimate values } & \multicolumn{5}{|c|}{ Most and least preferred } \\
\cline { 2 - 5 } & $\mathbf{1}$ & $\mathbf{2}$ & $\mathbf{3}$ & $\mathbf{1 8}$ \\
\hline Health & 46 & 22 & 0 & 0 \\
\hline Self-respect & 15 & 10 & 30 & 0 \\
\hline $\begin{array}{c}\text { Providing financial support for } \\
\text { the family }\end{array}$ & 5 & 30 & 25 & 3 \\
\hline & $\mathbf{1}$ & $\mathbf{1 6}$ & $\mathbf{1 7}$ & $\mathbf{1 8}$ \\
\hline Safety & 10 & 12 & 36 & 26 \\
\hline Exciting life & 0 & 7 & 26 & 12 \\
\hline Beauty of the world & 0 & 17 & 18 & 28 \\
\hline
\end{tabular}

The subjects' lifestyles stressed the advantage of economic values. The "economic man" treated everything that is useful and practical as the highest value, and also applied the criteria of utility in evaluating people. He did not search for truth for its own sake, but only as it was applied in practice. For him, truth is a means to obtain power and influence. The values selected by young people testified to their individual attitudes and, as a result, to their more general lifestyles. This study has provided a positive answer to the question concerning the relationship between the hierarchical values and the lifestyle of the 90 managers, suggesting that their values are realized in their lifestyle, whether selected by themselves or imposed by the surrounding world, fashion, or advertising.

Table 3 Hierarchy of Ultimate Values Among the Participants ( $\mathrm{N}=90)$, Level of Significant Differences

The women participating in the study seemed to have a more coherent hierarchy of values than the men. The values selected were significantly different, while there were no such differences within the rejected values. It can be concluded that the basic motives from which people select particular values favor understanding their lifestyle and personality. The intention of this paper has been to study the associations between the hierarchy of values and the lifestyles of managers in a automotive company. Psychological research of values is frequently limited to their evaluation and the application of a hierarchy. The results obtained in this study significantly differentiated the women and men with respect to their ultimate values. The following values appeared to be the most statistically differentiating: "outstanding successes" (0.001), "social recognition", "enjoyment of life" (0.001) and "comfortable life" (0.05). Within the selected lifestyle, the participants ranked values in the following order: economic, social, political, aesthetic, religious, and theoretical. Similar conclusions were drawn in previous research Mróz [18,20].

Table 3: Hierarchy of ultimate values among the participants $(\mathrm{N}=90)$, level of significant differences.

\begin{tabular}{|c|c|c|c|c|c|c|c|}
\hline \multirow{2}{*}{ Ultimate values } & \multirow{2}{*}{$\begin{array}{c}\text { Women } \mathrm{N}=60 \\
\text { Mean }\end{array}$} & \multirow[b]{2}{*}{ Median } & \multirow[b]{2}{*}{ SD } & \multirow{2}{*}{$\begin{array}{c}\text { Men } \mathbf{N}=30 \\
\text { Mean }\end{array}$} & \multirow[b]{2}{*}{ Median } & \multirow[b]{2}{*}{ SD } & \multirow{2}{*}{$\mathbf{p}$} \\
\hline & & & & & & & \\
\hline Safety & 12.5 & 14.0 & 5.0 & 10.8 & 11.0 & 4.3 & - \\
\hline Mature love & 6.30 & 6.0 & 5.0 & 8.4 & 9.0 & 4.9 & - \\
\hline Wisdom & 11.0 & 10.0 & 2.6 & 12.4 & 15.0 & 4.7 & - \\
\hline Beauty of the world & 10.4 & 10.0 & 4.9 & 9.9 & 12.0 & 4.6 & - \\
\hline Peace in the world & 12.3 & 13.0 & 6.3 & 14.1 & 16.1 & 4.1 & - \\
\hline True friendship & 8.1 & 8.0 & 5.2 & 7.8 & 7.0 & 3.7 & - \\
\hline Enjoyment of life & 9.9 & 10.0 & 3.8 & 13.0 & 13.0 & 4.7 & 0.001 \\
\hline Equality of people & 12.1 & 15.0 & 6.5 & 14.4 & 17.0 & 5.4 & - \\
\hline Outstanding successes & 7.9 & 8.0 & 4.0 & 5.1 & 3.1 & 4.0 & 0.001 \\
\hline Self-respect & 10.1 & 11.0 & 4.7 & 9.0 & 8.0 & 4.8 & - \\
\hline Social recognition & 7.9 & 8.0 & 3.9 & 11.1 & 11.0 & 5.6 & 0.001 \\
\hline Inner peace and harmony & 8.0 & 8.0 & 5.2 & 9.4 & 11.0 & 4.7 & - \\
\hline Personal freedom & 5.1 & 4.0 & 2.8 & 5.0 & 3.0 & 4.3 & - \\
\hline Comfortable life & 7.9 & 6.0 & 5.2 & 5.2 & 3.5 & 4.1 & 0.05 \\
\hline $\begin{array}{l}\text { Providing financial support for the } \\
\text { family }\end{array}$ & 9.8 & 11.0 & 4.8 & 7.7 & 8.0 & 5.3 & - \\
\hline
\end{tabular}




\begin{tabular}{|c|c|c|c|c|c|c|c|}
\hline Salvation & 11.90 & 10.0 & 4.7 & 13.3 & 16.1 & 4.1 & - \\
\hline Health & 3.7 & 2.0 & 3.6 & 5.7 & 5.0 & 3.4 & - \\
\hline Exciting life & 10.3 & 11.0 & 4.7 & 12.1 & 12.0 & 3.5 & - \\
\hline
\end{tabular}

The participants' hierarchy of values and their lifestyles resulting from them do not seem to fulfill an integrative role. Such values as "mature love", "true friendship" or even "providing financial support for the family" take distant places in their hierarchies. Their lifestyles are characterized by a significant margin of economic and utilitarian values - a rather "have" than "be" attitude (the last place among theoretical values and second to last among the religious ones). It may be assumed that this group's evaluative abilities have not evolved yet from the extremely subjective to the more objective ones. The conclusions presented above, resulting from the study on the hierarchy of values and lifestyle among young economists, could become the starting point for a discussion concerning managers healthy and unhealthy lifestyles Mróz [17]; Sey et al. [13].

\section{Conclusion}

The Lean Manufacturing concept of managing employee knowhow with respect to implementing changes in an enterprise or organization makes sense when superiors are able to convince employees that they should change their work habits. It is apparent that applying updated technical tools is more sensible and effective when employees accept them. However, the results of this study have shown that changes and professional success are not important in the hierarchy of values by which the managers guided in their lives. Therefore, this study strongly suggests that chances of succeeding in implementing significant changes in the Lean Manufacturing system without first demonstrating their benefits to the employees are poor. Both the type of work and a greater awareness of employee importance on the job market favor such a ranking. The hierarchy of values shows that the medium-rank managers concentrate more on individual values and less on the social ones. Lean Manufacturing can be applied to all departments of a automotive company, including those not directly connected with the production department, for example accounting, customer services and various technical units; and it improves company operations.

However, implementing Lean Manufacturing is associated with the full acceptance of the workers and managers. The article clearly shows the role of the hierarchy of values for managers' functioning during changes. This is also significant in any changing economic reality (emerging economies, emerging markets). Managers values are important in many changing or emerging economies - not only in management - for developing competitiveness and economic growth.

\section{References}

1. Rokeach M (1973) The Nature of Human Values. Free Press, New York, USA.

2. Katz RL (1982) Managing careers: The Influence of job and group longevities. In: Katz R (Eds.). Career Issues in Human Resource Management. Englewood cliffs NJ: Prentice Hall pp. 154-181.
3. Super DE (1957) The psychology of careers. Harper \& Row, New York, USA.

4. Stoner JAF, Wanker C (1996) Kierowanie. Warszawa: PWE.

5. Mróz B (2011a) Satisfying work and its purpose in men's lives: Positive aspects of a professional relationship. Polish Journal of Applied Psychology 9(1): 109-128.

6. Katz RL (1982) Managing careers: The Influence of job and group longevities. In Katz R (Ed.), Career Issues in Human Resource Management. Englewood cliffs NJ: Prentice Hall pp. 154-181.

7. Kożusznik B (2011) Zachowania człowieka w organizacji. Warszawa: Wydawnictwo Ekonomiczne.

8. Hornowska E, Paluchowski WJ (2001) Rozwój zawodowy - podstawowe założenia. In Listwan T, Witkowski S (Eds.), Sukces w zarządzaniu. Problemy organizacyjno-zarządcze i psychospołeczne. Wrocław: Wydawnictwo Akademii Ekonomicznej im. Oskara Langego pp. 230-256.

9. Brzozowski P (1989) Skala wartości - polska wersja testu Miltona Rokeacha. In Drwal RŁ (Ed.), Techniki kwestionariuszowe w diagnostyce psychologicznej. Lublin: Wydawnictwo UMCS pp. 81-122.

10. Allport G (1966) Zeszyt Postaw Wartościujących. Warszawa: Pracownia Psychometryczna PAN.

11. Brzozowski P (2007) Wzorcowa hierarchia wartości. Polska, Europejska czy uniwersalna? Psychologiczne badania empiryczne. Lublin: Wydawnictwo UMCS.

12. Oleś P (1989) Wartościowanie a osobowość. Psychologiczne badania empiryczne. Lublin: RW KUL.

13. Czerska J (2002) Role pracowników w transformacji Lean. Gdańsk: Wydawnictwo Ekonomiki i Organizacji Przedsiębiorstw.

14. Mróz B (2011b) Poczucie jakości życia u pracowników wyższego szczebla: uwarunkowania osobowościowe i aksjologiczne. Warszawa: Wydawnictwo Naukowe Scholar.

15. Mróz B (2012) Various management forms and their determinants in the hierarchy of managerial values and self-concepts. In: Mróz B (Eds.). Functioning in the Workplace. Quantitative and Qualitative Psychological Research. Warszawa: Wydawnictwo Naukowe Scholar p. 15-29.

16. Kozminski AK (2008) Anatomy of systemic change Polish management in transition. Communist and Post-Communist Studies 41(3): 263-280.

17. Oleś P (2000) Psychologia przełomu połowy życia. Lublin: TN KUL.

18. Mróz B (2010) Psychosocial determinants of the production managers' hierarchy of values in the light of Lean Manufacturing and Positive Psychology. In: Pańka E, Kwiatkowska A (Eds.). Proceedings of the $6^{\text {th }}$ European Conference on Management, Leadership and Governance. Wrocław: Academic Publishing UK Ltd, pp. 249-257.

19. Super DE (1985) Coming of Age in Middletown. Careers in the Making. American Psychologists 40(4): 405-414.

20. Womack JP, Jonem DT (2001) Lean Thinking. Warszawa: Centrum Informacji Inżyniera.

21. Rokeach M (1968) Beliefs, Attitudes and Values. San Francisco: Jassey - Bass, Inc.

22. Rokeach M (1979) Change and Stability in American Value Systems, 1968 - 1971. In: M Rokeach (Eds.). Understanding Human Values, New York: The Free Press, pp. 129-147. 
23. Roztocki N, Weistroffer HR (2008) Information technology in transition economies. Journal of Global Information Technology Management 11(4): 2-9.

24. Liker JK (2005) Droga Toyoty - 14 zasad zarządzania wiodącej firmy produkcyjnej świata. Warszawa: Wydawnictwo MT Biznes.

25. Mróz B (2006) Hierarchy of values and its consequences for the lifestyles selected among young people. Annales UMCS, Sectio D Medicina 4: 61 64 .

26. Brzozowski P (1995) Skala wartości Schelerowskich - SWS. Podręcznik Warszawa: Pracownia Testów Psychologicznych PTP.

ISSN: 2574-1241

DOI: 10.26717/BJSTR.2018.10.001904

Barbara Mróz. Biomed J Sci \& Tech Res

(c) (P) This work is licensed under Creative Commons Attribution 4.0 License

Submission Link: https://biomedres.us/submit-manuscript.php
27.Goleman D (1997) Inteligencja emocjonalna. Poznań: Wydawnictwo Media Rodzina.

28. Hawkins RJ (2002) The Global Information Technology Report 20012002. New York - Oxford: Oxford University Press.

29. Mróz B (2007) Health and environment protection as a value in a group of head nurses. Polish Journal of Environmental Studies 16(5A): 362368.

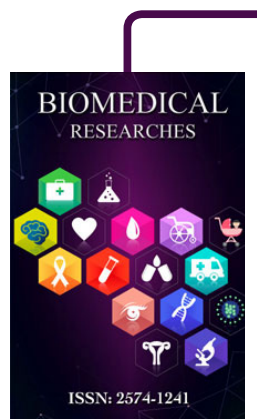

Assets of Publishing with us

- Global archiving of articles

- Immediate, unrestricted online access

- Rigorous Peer Review Process

- Authors Retain Copyrights

- Unique DOI for all articles 